\title{
Inactivation and Membrane Damage Mechanism of Slightly Acidic Electrolyzed Water on Pseudomonas deceptionensis CM2
}

\author{
Xiao Liu ${ }^{1,2,3}$, Mingli Zhang ${ }^{1,2,3}$, Xi Meng ${ }^{1,2,3}$, Xiangli He ${ }^{1,2,3}$, Weidong Zhao ${ }^{1,2,3}$, Yongji Liu ${ }^{4, *}$ and Yu He ${ }^{5, *}$ \\ 1 College of Food and Bioengineering, Zhengzhou University of Light Industry, Zhengzhou 450001, China; \\ liuxiao19870515@163.com (X.L.); zhang199412082021@163.com (M.Z.); miracle777777788@163.com (X.M.); \\ Xiang777791@163.com (X.H.); zhao2021519@163.com (W.Z.) \\ 2 Henan Key Laboratory of Cold Chain Food Quality and Safety Control, Zhengzhou University of Light \\ Industry, Zhengzhou 450001, China \\ 3 Henan Collaborative Innovation Center of Food Production and Safety, Zhengzhou 450001, China \\ 4 Department of Nutrition, Henry Fok School of Food Science and Engineering, Shaoguan University, \\ Shaoguan 512000, China \\ 5 College of Food and Biotechnology Engineering, Xuzhou University of Technology, Xuzhou 221018, China \\ * Correspondence: yjliu@sgu.edu.cn (Y.L.); heyuxinxin1120@163.com (Y.H.)
}

Citation: Liu, X.; Zhang, M.; Meng, X.; He, X.; Zhao, W.; Liu, Y.; He, Y. Inactivation and Membrane Damage Mechanism of Slightly Acidic Electrolyzed Water on Pseudomonas deceptionensis CM2. Molecules 2021, 26, 1012. https://doi.org/10.3390/ molecules26041012

Academic Editor: Junhu Cheng

Received: 16 January 2021

Accepted: 10 February 2021

Published: 14 February 2021

Publisher's Note: MDPI stays neutral with regard to jurisdictional claims in published maps and institutional affiliations.

Copyright: (c) 2021 by the authors. Licensee MDPI, Basel, Switzerland. This article is an open access article distributed under the terms and conditions of the Creative Commons Attribution (CC BY) license (https:// creativecommons.org/licenses/by/ $4.0 /)$.

\begin{abstract}
Pseudomonas is considered as the specific spoilage bacteria in meat and meat products. The purpose of this study was to evaluate the inactivation efficiency and mechanisms of slightly acidic electrolyzed water (SAEW) against Pseudomonas deceptionensis CM2, a strain isolated from spoiling chicken breast. SAEW caused time-dependent inactivation of $P$. deceptionensis CM2 cells. After exposure to SAEW ( $\mathrm{pH} 5.9$, oxidation-reduction potential of $945 \mathrm{mV}$, and $64 \mathrm{mg} / \mathrm{L}$ of available chlorine concentration) for $60 \mathrm{~s}$, the bacterial populations were reduced by 5.14 log reduction from the initial load of $10.2 \log _{10} \mathrm{CFU} / \mathrm{mL}$. Morphological changes in P. deceptionensis CM2 cells were clearly observed through field emission-scanning electron microscopy as a consequence of SAEW treatment. SAEW treatment also resulted in significant increases in the extracellular proteins and nucleic acids, and the fluorescence intensities of propidium iodide and n-phenyl-1-napthylamine in P. deceptionensis CM2 cells, suggesting the disruption of cytoplasmic and outer membrane integrity. These findings show that SAEW is a promising antimicrobial agent.
\end{abstract}

Keywords: slightly acidic electrolyzed water (SAEW); Pseudomonas deceptionensis CM2; inactivation; membrane damage mechanism

\section{Introduction}

Food spoilage is a major concern of the food industry, which is mainly caused by various microorganisms such as bacteria, molds, and yeasts [1]. It is estimated that approximately one-fourth of food is wasted worldwide every year due to food spoilage [2]. Bacteria are regarded as major sources of food spoilage [3], mainly including Shewanella, Clostridium, lactic acid bacteria, Brochothrix thermosphacta, Pseudomonas, Proteus, and Streptococcus [4]. Pseudomonas spp., a kind of Gram-negative aerobic bacteria, are considered to be the dominating spoilage bacteria in neutral $\mathrm{pH}$ and high protein content foods, such as milk, meat, fish, tofu, cheese, and vegetables $[5,6]$. The growth and metabolism of spoilage bacteria cause the production of unpleasant odor, unacceptable discoloration, and adverse changes in appearance and texture during the processing and storage of foods [1].

Hence, appropriate preservation methods should be developed to improve the safety and quality of foods, such as thermal processing and chemical preservatives [7]. However, traditional thermal processing technologies usually cause detrimental effects on the nutrient elements (such as proteins, lipids, carbohydrates, vitamins, and minerals) and the sensory properties of foods. Moreover, thermal processing also results in the degradation of heatsensitive elements (e.g., vitamins, phenolic compounds, and carotenoids) and promotes 
the formation of toxic compounds [8]. At present, various chemical preservatives are also widely used for food preservation, such as potassium sorbate, benzoic acid, nitrites, and sodium benzoate. However, the potential health hazards of these chemical preservatives have been attracting more attention in recent years [9]. For example, chlorine, one of the most commonly used disinfectants, can react with organic material to produce disinfection byproducts such as chloroform and haloacetic acids, which cause potential risks to human health [10]. In the past few years, nonthermal food processing technologies, such as highpressure carbon dioxide, high-pressure processing, pulsed electric field, ultrasound, and cold plasma, have been well developed for potential application in the food industries [11].

Electrolyzed water (EW), a new kind of sanitizer and cleaner, is produced by the electrolysis of a dilute sodium chloride solution [12]. According to the $\mathrm{pH}$ and available chlorine content (ACC), EW is generally classified into strongly acidic electrolyzed water (AEW) and slightly acidic electrolyzed water (SAEW) [13]. Compared to chlorine compounds, SAEW offers several advantages, such as highly effective, environmentally friendly, much safer, and low cost $[12,13]$. In recent years, SAEW has been widely used in food preservation, such as eggs, meat products, fruits, and vegetables. In addition, SAEW also can effectively remove pesticide residues and promote seed germination. Ongeng et al. [14] reported that the populations of psychrotrophs, lactic acid bacteria, and Enterobacteriacae cells on fresh-cut lettuce were reduced by 1.9, 1.2, and $1.3 \log$ reduction after $1 \mathrm{~min}$ of EW treatment, respectively. After neutral EW treatment and storage at 4 and $7^{\circ} \mathrm{C}$, the shelf life of minimally processed cabbage was extended by more than 5 days and 3 days, respectively [15]. However, the probable mechanisms of microbial inactivation by SAEW against spoilage bacteria are not well understood.

In our previous work, $P$. deceptionensis CM2 was isolated from spoiling chicken meat samples, which showed more than $99.5 \%$ similarity with P. deceptionensis DSM 26,521 in $16 \mathrm{~S}$ rRNA gene [16]. Hence, the purpose of this study was to evaluate the antimicrobial potential of SAEW against Pseudomonas deceptionensis CM2. Furthermore, the mechanisms underlying SAEW-induced bacterial inactivation were also well explored by measuring the permeability and integrity of cytoplasmic and outer membranes.

\section{Results and Discussions}

\subsection{Disinfection Efficacy of SAEW against P. deceptionensis CM2}

The disinfection efficacy of SAEW against $P$. deceptionensis $\mathrm{CM} 2$ is presented in Figure 1. The $\mathrm{pH}$, oxidation reduction potential (ORP), and available chlorine concentration (ACC) of SAEW were 5.9, $945 \mathrm{mV}$, and $64 \mathrm{mg} / \mathrm{L}$, respectively. As shown in Figure 1, the bactericidal efficiency of SAEW against $P$. deceptionensis CM2 was enhanced significantly with an increased treatment time $(p<0.05)$. The initial populations of $P$. deceptionensis $\mathrm{CM} 2$ cells were $10.2 \log _{10} \mathrm{CFU} / \mathrm{mL}$. After SAEW treatment for 15, 30, 45, and $60 \mathrm{~s}$, the populations of $P$. deceptionensis CM2 decreased by $1.26,2.91,4.08$, and $5.14 \log _{10} \mathrm{CFU} / \mathrm{mL}(p<0.05)$, respectively. Zeng et al. [17] reported that Staphylococcus. aureus cells were inactivated by $3.73 \log _{10} \mathrm{CFU} / \mathrm{mL}$ following 1 min treatment of $\mathrm{EW}$ (pH 2.3-2.7, $30.73 \mathrm{mg} / \mathrm{L}$ of ACC). It should be pointed out that microorganisms exhibit obvious differences in sensitivity to EW. As reported by Fenner et al. [18], Proteus mirabilis and S. aureus were more sensitive than Mycobacterium avium subsp. avium, Enterococcus faecium, and Pseudomona saeruginosa toward EW. Park et al. [19] also found that Bacillus cereus vegetative cells were much more sensitive to the combined treatments of EW and citric acid than spores. Therefore, more attention should be paid to the difference in sensitivity of microorganisms to EW when EW is used in food preservation. Kang et al. [20] found that plasma-activated water could effectively inactivate $P$. deceptionensis CM2 on chicken breasts, resulting in slight changes to the sensory qualities. Therefore, future studies are necessary to evaluate the antibacterial efficacy of SAEW for meat products. 


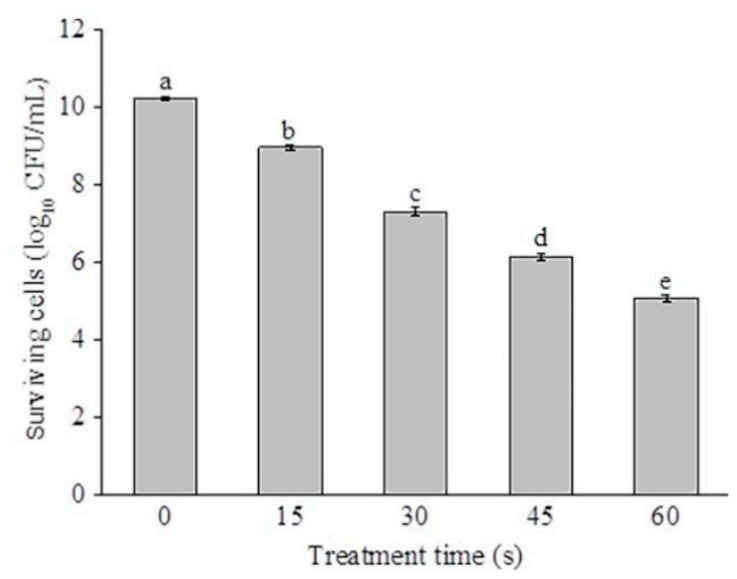

Figure 1. Inactivation effect of slightly acidic electrolyzed water (SAEW) against Pseudomonas deceptionensis CM2 cells. Bars labeled with different letters are significantly different from each other at $p<0.05$ (least significant difference (LSD) test).

Previous research has shown that the relative concentrations of chlorine compounds $\left(\mathrm{Cl}_{2}, \mathrm{HOCl}\right.$, and $\left.\mathrm{OCl}^{-}\right)$are mainly responsible for the bactericidal activity of EW [21,22]. Moreover, the hydroxyl radicals $(\bullet \mathrm{OH})$ were produced by un-ionized hypochlorous acid $(\mathrm{HOCl})$ in the SAEW, which could play an important role in microorganism inactivation [23]. Overall, numerous studies have demonstrated that $\mathrm{pH}, \mathrm{ACC}$, and ORP are the primary factors for the microbial inactivation inducted by EW [24].

\subsection{SAEW-Caused Morphological Changes of Bacterial Cells}

SAEW-caused morphological changes of $P$. deceptionensis CM2 were observed using a field emission-scanning electron microscope (FE-SEM). As shown in Figure 2a, the untreated P. deceptionensis CM2 cells were short and rod-shaped with an intact membrane, cell wall, and smooth surface. The cell morphology showed mild changes after $15 \mathrm{~s}$ of treatment (Figure 2b). After being treated by SAEW for $60 \mathrm{~s}$, the cell surfaces were rough, shriveled, and burst (Figure 2c). Similarly, Ding et al. [25] reported that remarkable changes in the ultrastructure of damaged S. aureus cells were observed after SAEW ( $\mathrm{pH}$ of 6.01, $31 \mathrm{mg} / \mathrm{L}$ of ACC, ORP of $810.7 \mathrm{mV}$ ) treatment by using a transmission electron microscope (TEM). The free radicals and oxidizing agents are generated in EW during the electrolysis of sodium chloride solution, which may be responsible for the deformation of cells [26].
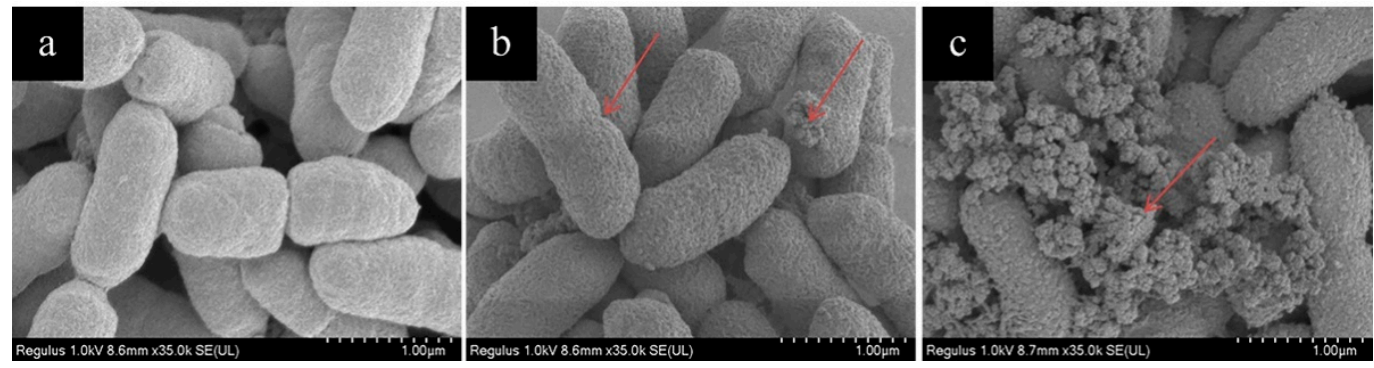

Figure 2. FE-SEM images of $P$. deceptionensis CM2 cells with SAEW treatment: (a) control cells, (b) cells treated with SAEW for $15 \mathrm{~s}$, (c) cells treated with SAEW for $60 \mathrm{~s}$.

\subsection{SAEW-Caused Alterations in the Cell Membrane Permeability}

SAEW-caused alterations in the cell membrane permeability were assessed by measuring the leakages of intracellular proteins and nucleic acids. As shown in Figure 3a, the extracellular protein and nucleic acid levels of the control cells were $0.09 \mathrm{mg} / \mathrm{mL}$ and $1.57 \mu \mathrm{g} / \mathrm{mL}$, respectively. The extracellular protein levels significantly increased after 
SAEW treatment in a time-dependent manner. Following SAEW treatment for $60 \mathrm{~s}$, the extracellular protein levels were increased to $0.31 \mathrm{mg} / \mathrm{mL}$, significantly higher than that of the untreated control cells $(p<0.05)$. Similar change trends were also observed for the extracellular nucleic acids (Figure $3 b$ ). These results are in agreement with the FE-SEM images of P. deceptionensis CM2 cells. Moreover, Zeng et al. [17] found that the leakage levels of proteins in E. coli and S. aureus cells increased to 20.50 and $15 \mu \mathrm{g} / \mathrm{mL}$, respectively, after $1 \mathrm{~min}$ treatment with EW (ACC of $12.40 \mathrm{mg} / \mathrm{L}$ and $37.3 \mathrm{mg} / \mathrm{L}$ towards E. coli and S. aureus), which were significantly higher than that of the untreated cells. Ding et al. [25] also reported the leakages of intracellular proteins, $\mathrm{K}^{+}$, and DNA in S. aureus cells after SAEW treatment.
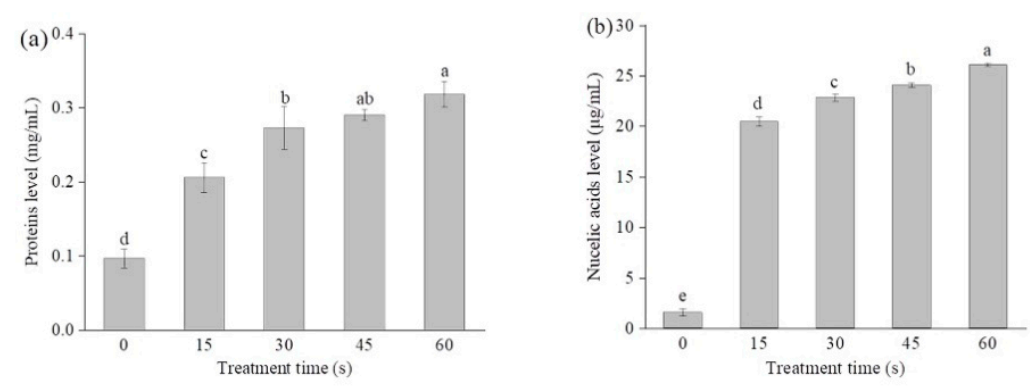

Figure 3. Leakages of intracellular proteins (a) and nucleic acids (b) changing with SAEW treatment in $P$. deceptionensis CM2 cells. Different letters above the bars indicate a statistically significant difference (LSD test, $p<0.05)$.

\subsection{Changes in the Cytoplasmic Membrane}

Cytoplasmic membranes are the key components to maintain the cell architecture and to respond to environmental stresses $[27,28]$. As a fluorescence probe, propidium iodide (PI) can only enter cells with injured cytoplasmic membranes, where it binds to nucleic acids and produces red fluorescence [29]. As shown in Figure 4, the relative PI fluorescence intensity of SAEW-treated cells significantly increased compared to the control $(p<0.05)$. After SAEW treatment for 15, 30, 45, and $60 \mathrm{~s}$, the PI fluorescence intensity of P. deceptionensis CM2 was significantly increased by $102.1 \%, 138.6 \%, 145 \%$, and $152.1 \%$ $(p<0.05)$, respectively. Similar findings were also reported by Ye et al. [30], who found that SAEW-treated E. coli cells exhibited higher PI fluorescence intensities than the untreated control cells. As shown in Figure 5, the number of cells with red fluorescence significantly increased with the extension of EW treatment time. In general, these findings suggest that the damage of cytoplasmic membranes may be responsible for the microbial inactivation caused by EW [31].

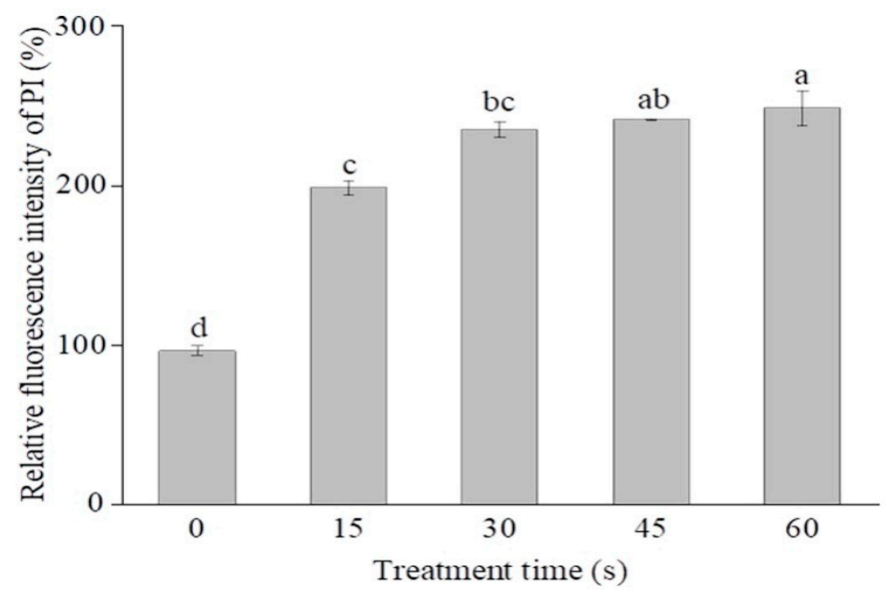

Figure 4. Changes in the membrane permeability of $P$. deceptionensis CM2 cells after SAEW treatment. Values marked with different letters are significantly different at $p<0.05$. 
Treatment time (s)

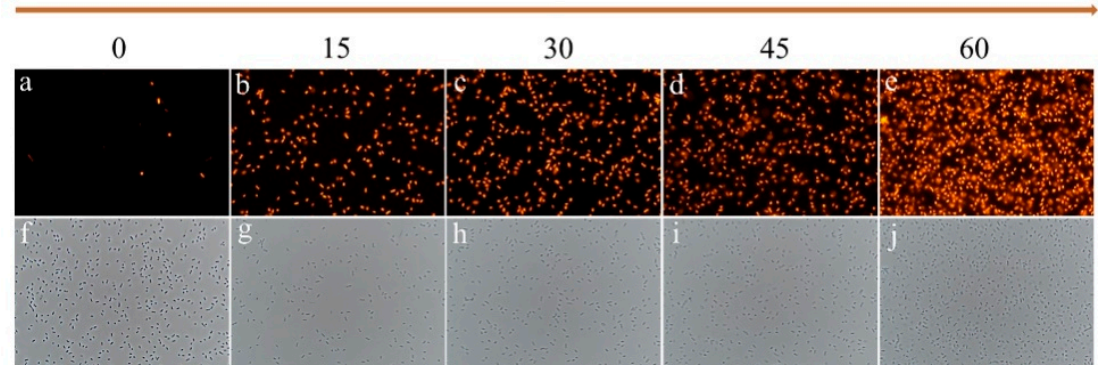

Figure 5. Fluorescence microscopic images of $P$. deceptionensis CM2 cells stained with propidium iodide (PI) $(400 \times)$. $(\mathbf{a}, \mathbf{f})$ : Control; $(\mathbf{b}, \mathbf{g})$ : treated with SAEW for $15 \mathrm{~s} ;(\mathbf{c}, \mathbf{h})$ : treated with SAEW for $30 \mathrm{~s} ;(\mathbf{d}, \mathbf{i})$ : treated with SAEW for $45 \mathrm{~s} ;(\mathbf{e}, \mathbf{j})$ : treated with SAEW for $60 \mathrm{~s}$. (a-e) indicated PI staining observation; ( $\mathbf{f}-\mathbf{j})$ indicated field observation.

\subsection{Changes in the Outer Membrane Permeabilization}

For Gram-negative bacteria, the outer membrane (OM) plays an important role in the rapid adaptation to various environmental stresses such as heat, acid, and antibiotics [32]. In this work, the n-phenyl-1-napthylamine (NPN) access assay was applied to assess the influences of SAEW on the OM permeabilization of P. deceptionensis CM2 cells. NPN is a neutral hydrophobic fluorescent probe, exhibiting low fluorescence quantum yield in an aqueous environment, but becomes strongly fluorescent in nonpolar or hydrophobic environments. Therefore, NPN is widely used to assess the damage of the outer membrane of Gram-negative bacteria [33]. As shown in Figure 6, SAEW treatment caused an increase in the NPN fluorescence intensity of $P$. deceptionensis CM2 cells. After being treated by SAEW for 15, 30, 45, and $60 \mathrm{~s}$, the NPN fluorescence intensity of P. deceptionensis CM2 cells was increased by $202 \%, 255 \%, 266 \%$, and $271 \%$, respectively, compared to the untreated cells $(p<0.05)$. These data indicate that SAEW disrupted the extracellular membranes of $P$. deceptionensis CM2 cells, which might contribute to the cell death [34]. Previous studies showed that AEW with high ORP caused the oxidation of sulfhydryl groups on cell surfaces and disturbed metabolic pathways inside the bacterial cells, which might be responsible for cell death [35,36]. In addition, active chlorine forms $\left(\mathrm{Cl}_{2}, \mathrm{HOCl}\right.$, and $\left.\mathrm{OCl}^{-}\right)$ are the main crucial substances for the damage to outer membrane [37].

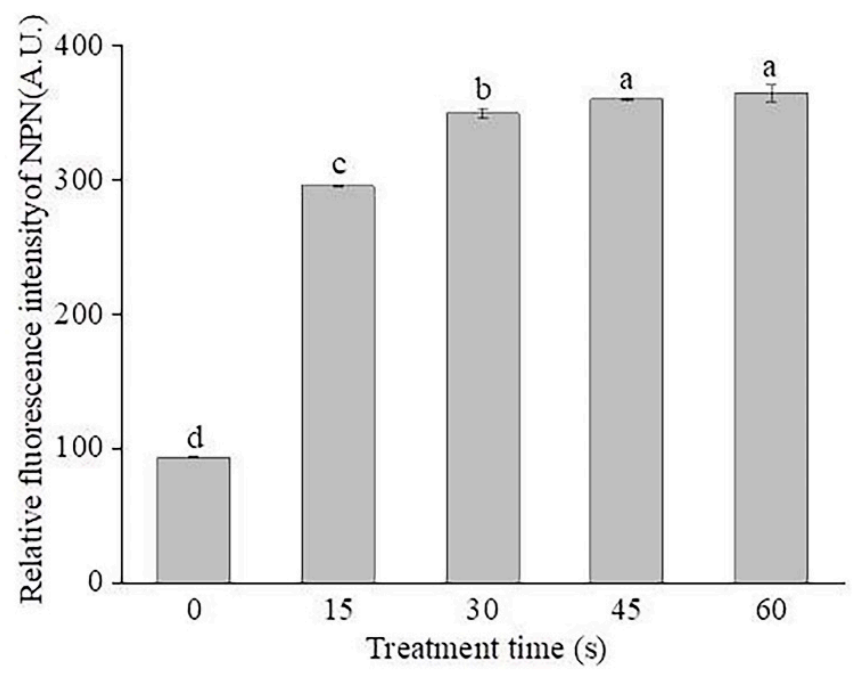

Figure 6. Changes in the outer membrane permeability of $P$. deceptionensis CM2 cells as determined by the n-phenyl-1-napthylamine (NPN) assay. Means with the different letters are significantly different from each other $(p<0.05)$. 


\section{Materials and Methods}

\subsection{Bacterial Culture and Preparation of Inoculums}

P. deceptionensis CM2 used in this study was isolated from spoiling chicken meat samples. A single colony of $P$. deceptionensis $\mathrm{CM} 2$ was transferred in $30 \mathrm{~mL}$ of nutrient broth (NB) medium (Beijing Land Bridge Technology Co., Ltd., Beijing, China) and incubated under shaking $(150 \mathrm{rpm})$ at $25^{\circ} \mathrm{C}$ for $24 \mathrm{~h}$. After centrifugation at $6000 \times g$ for $10 \mathrm{~min}$, the cells were collected and washed twice with sterile saline solution. The resulting pellets were resuspended in the same solution and the optical density at $600 \mathrm{~nm}\left(\mathrm{OD}_{600}\right)$ measured with a spectrophotometer (Shimadzu, Model UV 2450). According to the calibration curve for $\mathrm{OD}_{600}$ versus viable cell count, the bacterial solution was diluted to a final concentration of approximately 9 to $10 \log _{10}$ colony-forming units $(\mathrm{CFU}) / \mathrm{mL}$.

\subsection{Preparation of $S A E W$}

SAEW was generated by a MS-4000P SAEW generator (Medilox-s Co., Ltd., Seoul, South Korea) at a rate of $1.0 \mathrm{~L} / \mathrm{min}$. The $\mathrm{pH}, \mathrm{ORP}$, and ACC of SAEW were 5.9, $945 \mathrm{mV}$, and $64 \mathrm{mg} / \mathrm{L}$, respectively.

\subsection{Antimicrobial Test of SAEW}

The antimicrobial test of SAEW was performed by the method described previously [38]. Briefly, $1 \mathrm{~mL}$ of bacterial solution was incubated with $9 \mathrm{~mL}$ of SAEW for $0,15,30,45$, and $60 \mathrm{~s}$ at room temperature, respectively. Thereafter, $1 \mathrm{~mL}$ of the cell suspension was diluted with $9 \mathrm{~mL}$ of sterile neutralizing buffer solution $(0.5 \%$ sodium thiosulfate $+0.03 \mathrm{mmol} / \mathrm{L}$ phosphate buffer solution (PBS, $\mathrm{pH} 7.2-7.4)$ ). Then, $0.1 \mathrm{~mL}$ of diluted cells suspension was spread on plate count agar media (Beijing Land Bridge Technology Co., Ltd., Beijing, China), and then the plates were incubated at $25^{\circ} \mathrm{C}$ for $24 \mathrm{~h}$ (Figure 7). Finally, the number of colonies developed on the plates was determined and the results expressed as $\log _{10} \mathrm{CFU} / \mathrm{mL}$.

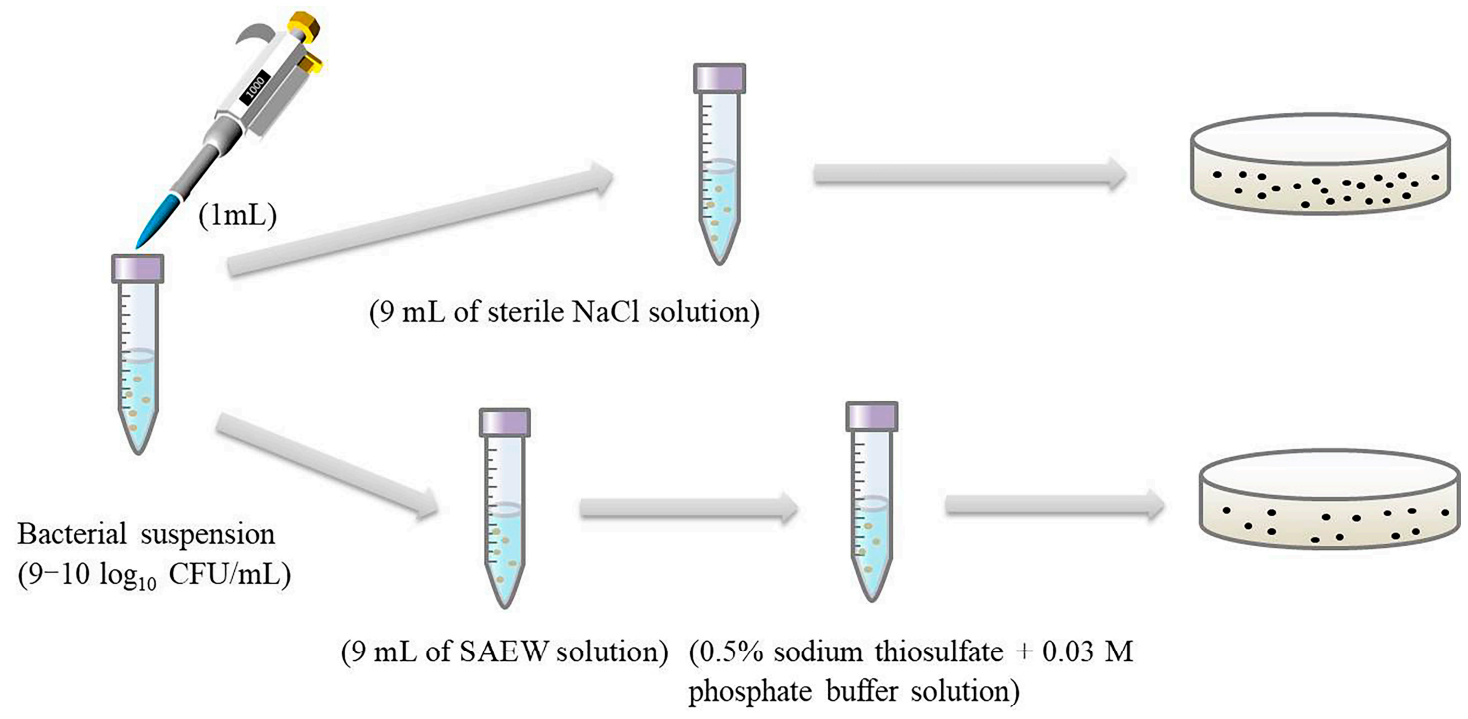

Figure 7. Schematic diagram of this work.

\subsection{Analysis of Cellular Morphology}

P. deceptionensis CM2 cells were treated with SAEW for 0,15 , or $60 \mathrm{~s}$ as described above. After each treatment, the bacterial cells were fixed with $2.5 \%$ glutaraldehyde solution at $4{ }^{\circ} \mathrm{C}$ for $4 \mathrm{~h}$ and then washed three times with PBS. The cells were then dehydrated in a graded series of ethanol $(30 \%, 50 \%, 70 \%, 90 \%$, and $100 \%, v / v)$ for $10 \mathrm{~min}$ each, and the ethanol was displaced by isoamyl acetate. The cells were dried and sputter-coated 
with gold particles, then observed by using a field emission-scanning electron microscope (FE-SEM) (JSM7001F, JEOL Ltd., Tokyo, Japan) [16].

\subsection{Leakage of Extracellular Proteins and Nucleic Acids}

The extracellular protein and nucleic acid contents of $P$. deceptionensis CM2 suspensions were measured using a previously reported method [39]. Briefly, after SAEW treatment for different times $(15,30,45$, and $60 \mathrm{~s})$, the bacterial suspensions were centrifuged $(10,000 \times g$ for $2 \mathrm{~min}, 4{ }^{\circ} \mathrm{C}$ ). The concentrations of proteins and nucleic acids in the supernatant were determined by an ultra-microspectrophotometer (Nanodrop 2000, Thermo Scientific, Wilmington, DE, USA) at a wavelength of 280 and $260 \mathrm{~nm}$, respectively.

\subsection{Assay of Cytoplasmic Membrane Permeability}

PI staining was used to assess the membrane permeability of $P$. deceptionensis CM2 cells treated by SAEW [40]. After SAEW treatment for 0, 15, 30, 45, and $60 \mathrm{~s}$, the bacterial cells were harvested by centrifugation, resuspended, and then stained with the PI solution (final concentration of $3.0 \mu \mathrm{mol} / \mathrm{L}$, Shanghai Macklin Biochemical Co., Ltd, Shanghai, China). After incubation in the dark at room temperature for $10 \mathrm{~min}$, the cells were harvested by centrifugation, washed, and then resuspended in PBS. The fluorescence was measured with a fluorescence spectrophotometer (Hitachi F-7000, Hitachi, Tokyo, Japan). The excitation and emission wavelengths were set at 485 and $635 \mathrm{~nm}$ (both with a $5 \mathrm{~nm}$ slit), respectively. The relative fluorescence intensity of PI was determined using the following equation:

$$
\text { Relative fluorescence intensity }=\mathrm{F}_{1} / \mathrm{F}_{0} \times 100 \%
$$

where the $F_{0}$ is the fluorescence intensity of untreated cells and $F_{1}$ is the fluorescence intensity of SAEW-treated cells.

The PI-stained cells were also observed under fluorescence microscopy (Eclipse 80i, Nikon, Japan).

\subsection{NPN Uptake Assay}

NPN uptake assay was used to investigate the effect of SAEW on the outer membrane permeability of bacterial cells [16]. Briefly, after SAEW treatment for 0, 15, 30, 45, and $60 \mathrm{~s}$, the samples were centrifuged $\left(6000 \times g, 4{ }^{\circ} \mathrm{C}, 10 \mathrm{~min}\right)$ and resuspended in $1 \mathrm{~mL}$ of HEPES (4-(2-hydroxyethyl)-1-piperazinee-thanesulfonic acid) buffer ( $5 \mathrm{mmol} / \mathrm{L}, \mathrm{pH} 7.2)$. One milliliter of bacterial suspension was mixed with $20 \mu \mathrm{L}$ of NPN solution (Shanghai Macklin Biochemical Co., Ltd, Shanghai, China) at a final concentration of $10 \mu \mathrm{mol} / \mathrm{L}$, and then incubated in the dark at $25^{\circ} \mathrm{C}$ for $10 \mathrm{~min}$. Thereafter, the fluorescence intensity was recorded using an F-7000 fluorescence spectrophotometer at an excitation wavelength of $350 \mathrm{~nm}$ and an emission wavelength of $401 \mathrm{~nm}$. The relative fluorescence intensity of NPN was calculated according to Equation (1).

\subsection{Statistical Analysis}

All experiments were performed in triplicate and the data were expressed as mean \pm standard deviation (SD). The statistical significance was evaluated by one-way analysis of variance (ANOVA) and the least significant difference (LSD) test using SPSS 23.0 software (IBM, Chicago, IL, USA) at a significant level of $p<0.05$.

\section{Conclusions}

The results of this work indicated that SAEW could effectively inactivate P. deceptionensis CM2 cells in a time-independent way. SAEW disrupted the cytoplasmic and outer membranes of $P$. deceptionensis CM2 cells, thereby resulting in the leakage of intracellular ingredients (e.g., proteins and nucleic acids). The inactivation of $P$. deceptionensis CM2 cells may be mainly due to the disruption of cellular membrane caused by SAEW. In future studies, the mechanism of inactivation by SAEW should be elucidated from the molecular level by using multiomics technologies, such as metabolomics, proteomics, and 
transcriptome. In addition, the applications of EW against spoilage bacteria in foods also need to be examined in the future.

Author Contributions: Conceptualization, X.L.; formal analysis, X.L. and Y.H.; funding acquisition, X.L., X.H., and Y.L.; investigation, M.Z. and X.M.; methodology, W.Z.; supervision, X.L. and X.H.; writing—original draft, M.Z. and X.L.; writing—review and editing, X.L., Y.L. and Y.H. All authors have read and agreed to the published version of the manuscript.

Funding: The work was financially supported by the National Natural Science Foundation of China (No. 31701672), Key Science and Technology Project of Henan province (No. 192102110106), National Natural Science Foundation of Henan province (No. 202300410497), Doctoral Scientific Research Foundation of Zhengzhou University of Light Industry (No. 2016BSJJ023), and the Natural Science Foundation of Guangdong Province (No. 2018A030310041).

Date Availability Statement: The data presented in this study are available on request from the corresponding author.

Acknowledgments: The authors acknowledge the Henan Key Laboratory of Cold Chain Food Quality and Safety Control and Henan Collaborative Innovation Center of Food Production and Safety.

Conflicts of Interest: The authors declare no conflict of interest.

\section{References}

1. Odeyemi, O.A.; Alegbeleye, O.O.; Strateva, M.; Stratev, D. Understanding spoilage microbial community and spoilage mechanisms in foods of animal origin. Compr. Rev. Food Sci. Food Saf. 2020, 19, 311-331. [CrossRef]

2. Gram, L.; Ravn, L.; Rasch, M.; Bruhn, J.B.; Christensen, A.B.; Givskov, M. Food spoilage-interactions between food spoilage bacteria. Int. J. Food Microbiol. 2002, 78, 79-97. [CrossRef]

3. Iulietto, M.F.; Sechi, P.; Borgoni, E.; Cenci-Goga, B.T. Meat Spoilage: A critical review of a neglected alteration due to ropy slime producing bacteria. Ital. J. Anim. Sci. 2015, 14, 4011. [CrossRef]

4. Wang, G.Y.; Wang, H.H.; Han, Y.W.; Xing, T.; Ye, K.P.; Xu, X.L.; Zhou, G.H. Evaluation of the spoilage potential of bacteria isolated from chilled chicken in vitro and in situ. Food Microbiol. 2017, 63, 139-146. [CrossRef] [PubMed]

5. Correa, A.P.F.; Doroit, D.J.; Velho, R.V.; Brandelli, A. Hydrolytic potential of a psychrotrophic Pseudomonas isolated from refrigerated raw milk. Braz. J. Microbiol. 2011, 42, 1479-1484. [CrossRef] [PubMed]

6. Franzetti, L.; Scarpellini, M. Characterisation of Pseudomonas spp. isolated from foods. Ann. Microbiol. 2007, 57, 39-47. [CrossRef]

7. Jamnrak, A.R.; Vukušić, T.; Donsi, F.; Paniwnyk, L.; Djekic, I. Three pillars of novel nonthermal food technologies: Food safety, quality, and environment. J. Food Qual. 2018, 2018, 8619707.

8. D'Evoli, L.; Lombardi-Boccia, G.; Lucarini, M. Influence of heat treatments on carotenoid content of cherry tomatoes. Foods 2013, 2, 352-363. [CrossRef]

9. Mei, J.; Ma, X.; Xie, J. Review on natural preservatives for extending fish shelf life. Foods 2019, 10, 490. [CrossRef]

10. Gadelha, J.R.; Allende, A.; López-Gálvez, F.; Fernández, P.; Gil, M.I.; Egea, J.A. Chemical risks associated with ready-to-eat vegetables: Quantitative analysis to estimate formation and/or accumulation of disinfection byproducts during washing. EFSA J. 2019, 17, e170913.

11. Zhao, Y.M.; de Alba, M.; Sun, D.W.; Tiwari, B. Principles and recent applications of novel non-thermal processing technologies for the fish industry-a review. Crit. Rev. Food Sci. Nutr. 2019, 59, 728-742. [CrossRef]

12. Rahman, S.M.E.; Khan, I.; Oh, D.H. Electrolyzed water as a novel sanitizer in the food industry: Current trends and future perspectives. Compr. Rev. Food Sci. Food Saf. 2016, 15, 471-490. [CrossRef] [PubMed]

13. Li, Z.H.; Zhou, B.; Li, X.T.; Li, S.G. Effect of alkaline electrolyzed water on physicochemical and structural properties of apricot protein isolate. Food Sci. Biotechnol. 2018, 28, 15-23. [CrossRef] [PubMed]

14. Ongeng, D.; Devlieghere, F.; Debevere, J.; Coosemans, J.; Ryckeboer, J. The efficacy of electrolysed oxidising water for inactivating spoilage microorganisms in process water and on minimally processed vegetables. Int. J. Food Microbiol. 2006, 109, 187-197. [CrossRef] [PubMed]

15. Gómez-López, V.M.; Ragaert, P.; Ryckeboer, J.; Jeyachchandran, V.; Debevere, J.; Devlieghere, F. Shelf-life of minimally processed cabbage treated with neutral electrolysed oxidising water and stored under equilibrium modified atmosphere. Int. J. Food Microbiol. 2007, 117, 91-98. [CrossRef]

16. Xiang, Q.S.; Kang, C.D.; Niu, L.Y.; Zhao, D.B.; Li, K.; Bai, Y.H. Antibacterial activity and a membrane damage mechanism of plasma-activated water against Pseudomonas deceptionensis CM2. LWT-Food Sci. Technol. 2018, 96, 395-401. [CrossRef]

17. Zeng, X.P.; Tang, W.W.; Ye, G.Q.; Ouyang, T.; Tian, L.; Ni, Y.M.; Li, P. Studies on disinfection mechanism of electrolyzed oxidizing water on E. coli and Staphylococcus aureus. J. Food Sci. 2010, 75, M253-M260. [CrossRef]

18. Fenner, D.; Burge, B.; Kayser, H.; Wittenbrink, M. The anti-microbial activity of electrolysed oxidizing water against microorganisms relevant in veterinary medicine. J. Vet. Med. Ser. B 2006, 53, 133-137. [CrossRef] [PubMed] 
19. Park, Y.B.; Guo, J.Y.; Rahman, S.M.E.; Ahn, J.; Oh, D.H. Synergistic effect of electrolyzed water and citric acid against Bacillus cereus cells and spores on cereal grains. J. Food Sci. 2009, 74, M185-M189. [CrossRef]

20. Kang, C.D.; Xiang, Q.S.; Zhao, D.B.; Wang, W.J.; Niu, L.Y.; Bai, Y.H. Inactivation of Pseudomonas deceptionensis CM2 on chicken breasts using plasma-activated water. J. Food Sci. Technol. 2019, 56, 4938-4945. [CrossRef]

21. Len, S.V.; Hung, Y.C.; Erickson, M.; Kim, C. Ultraviolet spectrophotometric characterization and bactericidal properties of electrolyzed oxidizing water as influenced by amperage and pH. J. Food Protect. 2000, 63, 1534-1537. [CrossRef]

22. Koseki, S.; Yoshida, K.; Isobe, S.; Itoh, K. Efficacy of acidic electrolyzed water for microbial decontamination of cucumbers and strawberries. J. Food Protect. 2004, 67, 1247-1251. [CrossRef]

23. Zhang, C.L.; Lu, Z.H.; Li, Y.Y.; Shang, Y.C.; Zhang, G.; Cao, W. Reduction of Escherichia coli O157:H7 and Salmonella enteritidis on mung bean seeds and sprouts by slightly acidic electrolyzed water. Food Control 2011, 22, 792-796. [CrossRef]

24. Huang, Y.R.; Hung, Y.C.; Hsu, S.Y.; Huang, Y.; Hwang, D.F. Application of electrolyzed water in the food industry. Food Control 2008, 19, 329-345. [CrossRef]

25. Ding, T.; Xuan, X.T.; Li, J.; Chen, S.G.; Liu, D.H.; Ye, X.Q.; Shi, J.; Xue, S.J. Disinfection efficacy and mechanism of slightly acidic electrolyzed water on Staphylococcus aureus in pure culture. Food Control 2016, 60, 505-510. [CrossRef]

26. Ersoy, Z.G.; Dinc, O.; Cinar, B.; Gedik, S.T.; Dimoglo, A. Comparative evaluation of disinfection mechanism of sodium hypochlorite, chlorine dioxide and electroactivated water on Enterococcus faecalis. LWT-Food Sci. Technol. 2018, 102, 205-213. [CrossRef]

27. Casares, D.; Escribá, P.V.; Rosselló, C.A. Membrane lipid composition: Effect on membrane and organelle structure, function and compartmentalization and therapeutic avenues. Int. J. Mol. Sci. 2019, 20, 2167. [CrossRef]

28. Rowlett, V.W.; Mallampalli, V.K.P.S.; Karlstaedt, A.; Dowhan, W.; Taegtmeyer, H.; Margolin, W.; Vitrac, H. Impact of membrane phospholipid alterations in Escherichia coli on cellular function and bacterial stress adaptation. J. Bacteriol. 2017, 199, e00849. [CrossRef]

29. Berney, M.; Hammes, F.; Bosshard, F.; Weilenmann, H.U.; Egli, T. Assessment and interpretation of bacterial viability by using the LIVE/DEAD BacLight kit in combination with flow cytometry. Appl. Environ. Microbiol. 2007, 73, 3283-3290. [CrossRef] [PubMed]

30. Ye, Z.Y.; Wang, S.; Chen, T.; Gao, W.S.; Zhu, S.M.; He, J.S.; Han, Z.Y. Inactivation mechanism of Escherichia coli induced by slightly acidic electrolyzed water. Sci. Rep. 2017, 7, 6279. [CrossRef] [PubMed]

31. Zeng, X.P.; Ye, G.Q.; Tang, W.W.; Ouyang, T.; Tian, L.; Ni, Y.M.; Li, P. Fungicidal efficiency of electrolyzed oxidizing water on Candida albicans and its biochemical mechanism. J. Biosci. Bioeng. 2011, 112, 86-91. [CrossRef] [PubMed]

32. Breijyeh, Z.; Jubeh, B.; Karaman, R. Resistance of gram-negative bacteria to current antibacterial agents and approaches to resolve it. Molecules 2020, 25, 1340. [CrossRef]

33. Gravel, J.; Paradis-Bleau, C.; Schmitzer, A.R. Adaptation of a bacterial membrane permeabilization assay for quantitative evaluation of benzalkonium chloride as a membrane-disrupting agent. Medchemcomm 2017, 8, 1408-1413. [CrossRef]

34. Guo, Y.R.; Liu, Y.; Zhang, Z.H.; Chen, M.H.; Zhang, D.X.; Tian, C.L.; Liu, M.C.; Jiang, G.T. The antibacterial activity and mechanism of action of luteolin against trueperella pyogenes. Infect. Drug Resist. 2020, 2020, 1697-1711. [CrossRef]

35. Liao, L.B.; Chen, W.M.; Xiao, X.M. The generation and inactivation mechanism of oxidation-reduction potential of electrolyzed oxidizing water. J. Food Eng. 2007, 78, 1326-1332. [CrossRef]

36. Park, H.; Hung, Y.C.; Chung, D.H. Effects of chlorine and $\mathrm{pH}$ on efficacy of electrolyzed water for inactivating Escherichia coli O157:H7 and Listeria monocytogenes. Int. J. Food Microbiol. 2004, 91, 13-18. [CrossRef]

37. Orejel, J.R.C.; Cano-Buendia, J.A. Applications of electrolyzed water as a sanitizer in the food and animal-by products industry. Processes 2020, 8, 534. [CrossRef]

38. Cao, W.; Zhu, Z.W.; Shi, Z.X.; Wang, C.Y.; Li, B.M. Efficiency of slightly acidic electrolyzed water for inactivation of Salmonella enteritidis and its contaminated shell eggs. Int. J. Food Microbiol. 2009, 130, 88-93. [CrossRef]

39. Xiang, Q.; Liu, X.; Li, J.; Liu, S.; Zhang, H.; Bai, Y. Effects of dielectric barrier discharge plasma on the inactivation of Zygosaccharomyces rouxii and quality of apple juice. Food Chem. 2018, 254, 201-207. [CrossRef] [PubMed]

40. Boda, S.K.; Broda, J.; Schiefer, F.; Weber-Heynemann, J.; Hoss, M.; Simon, U.; Basu, B.; Jahnen-Dechent, W. Cytotoxicity of ultrasmall gold nanoparticles on planktonic and biofilm encapsulated gram-positive Staphylococci. Small 2015, 11, 3183-3193. [CrossRef] 